\title{
Between the Spillover and the Spillout: Tracing the Evolution of the Czech Global Justice Movement*
}

\author{
JIŘí NAVRÁTIL** \\ Masaryk University, Brno
}

\begin{abstract}
This article conceptually and empirically focuses on various dimensions of the Czech Global Justice Movement (GJM) dynamics. In discussions on the Western GJM it is possible to distinguish two main perspectives on the movement's evolution, which were formulated in different contexts. One view claims that no such single movement exists anymore; it has already declined (or 'spilled out' into different field of activism). The other view argues that the movement is undergoing profound changes but its major principles and identity - at least latently - have survived. The aim of this article is twofold. First, it strives to re-introduce the concepts of 'spillover' and 'spillout' as multidimensional social processes and operationalise them to apply to the evolution of the Czech GJM in 2003-2009. Second, the article empirically traces the thematic shift of the Czech GJM towards anti-war activism and demonstrates that it is the movement's collective identity that constitutes a key obstacle to its spillout in an unfavourable environment.
\end{abstract}

Keywords: contentious politics, collective identity, social movement spillover, global justice movement, anti-war activism, Czech Republic

Sociologický časopis/Czech Sociological Review, 2010, Vol. 46, No. 6: 913-944

\section{Introduction}

The Global Justice Movement (GJM) - sometimes called the anti-neoliberal movement or the alter-globalisation movement - has become a privileged object of research on social movements in the past decade. So far analyses of this movement have mostly focused on the form and composition of its mobilisation structures, its framing strategies, and its repertoire of action. However, partly as a consequence of its having matured, and partly as a result of the turbulent political environment that followed the events of $9 / 11$, and because of the growing impor-

\footnotetext{
* This article was prepared as part of work on the research project 'Political Parties and Representation of Interests in Contemporary European Democracies' funded by the Ministry of Education, Youth and Sports of the Czech Republic (No. MSM0021622407). The author gratefully acknowledges helpful suggestions from Ondřej Císař, Marek Skovajsa, and the anonymous reviewers of this article.

** Direct all correspondence to: Jiří Navrátil, Institute for Comparative Political Research, Faculty of Social Studies, Joštova 10, 60200 Brno, Czech Republic, e-mail: jirinav@fss.muni. cz.
} 
tance of the process paradigm in collective action research, there has also been a shift towards analysing its overall dynamics over time [Ayres 2005; Podobnik 2005; Tarrow 2005; Della Porta and Mosca 2007; Hosseini 2010]. In this context, studies have usually focused on the rise of the movement, its transformation, and its decline. However, there is still a considerable gap in the understanding of how precisely these processes evolve over time, what their basic structure is, and, most importantly, what properties of social movements are most crucial for the culmination of the movement.

This article draws attention to the problem of social movement continuity in time and argues that the manifest displacement of a movement's public protest activities or its framing in a different field of activism does not necessarily equate with its demise. Furthermore, and consistent with a long tradition of social movement theory and research (for an overview, see Hunt and Benford [2004]), it suggests that it is the collective identity of a social movement that is its least visible but most enduring feature and is the feature that serves as the movement's last hedge before it hollows out in a changing environment. The theoretical part of this article attempts to re-introduce the spillover/spillout framework of social movement analysis in order to grasp more accurately the evolution of the Czech GJM and the processes whereby it came to overlap with the anti-war activism that occurred between 2003 and 2009. This framework builds upon the original concepts of social movement 'spillover' [Meyer and Whittier 1994] and social movement 'spillout' [Tarrow and Hadden 2007], and integrates them with selected concepts and approaches in the field of social movement studies. Owing to the lack of relevant data and literature on Central and Eastern European global justice and anti-war activism, here these concepts are applied just to the Czech case. Nevertheless, even if the political protest in the post-communist setting represents a specific phenomenon within the realm of contemporary political contention [Szabó 1996; Císař 2008, 2010], this analysis could improve our understanding of the processes and outcomes of the dynamics of social movements.

The article focuses on meso-level analysis and opens with a brief description of the origins and development of the GJM in order to draft a working definition of this actor. Next, the concepts of social movement spillover and spillout are introduced and examined in more detail. The next part of the article describes the structure and evolution of the Czech GJM and analyses the processes whereby it shifted into anti-war activism. The article concludes by demonstrating that despite the 'obvious' eclipse of public GJM mobilisations and the change in the movement's framing, it only partially spilled into anti-war activism, without changing the ideological roots of its identity. 


\section{The movement in motion: the modes and development of the GJM}

The first waves of mass mobilisations against international economic institutions and their policies occurred in the 1970s and 1980s in recently industrialised countries such as Turkey, Morocco, and Chile [Walton and Ragin 1990: 876-877; Routledge 1996; Rothman and Oliver 2002]. These mobilisations reached Western countries during the 1990s and flourished there in response to growing transnational communication, organisational and institutional ties, and the opportunities provided by some international institutions [cf. Keck and Sikkink 1998; Smith 2008: 94-95]. The key event associated with the rise of the GJM as a relevant international actor was the Seattle anti-WTO mobilisation in 1999. Collective actors that had previously been considered as separate or even competing with each other (unions, environmentalists, etc.) joined together and organised a successful event that challenged the symbols and proponents of economic globalisation. The combination of success (the mobilisation managed to shut down the WTO meeting), extensive media coverage, and public attention made Seattle 1999 the founding myth and 'coming out' for the GJM, at least in the West [e.g. Munck 2007: 57; Juris 2008: 33].

The Seattle event showed the movement to be a manifold network of organisations, groups, and activists that is characterised by innovative strategies and repertoires. The latter derives from the GJM's rejection of existing models of interest representation and its preference for grass-roots politics. For this reason mass protest events became the principal vehicle for the GJM's collective identity and political character. Generally, there are two main modes of GJM activism. First, there are 'classic' counter-summits (i.e. the mass street protests held during the official summits of certain key international economic and political institutions, such as the protests in Washington against the IMF/WB in 2000, in Seattle against the WTO in 1999, or in Genoa against the G8 in 2001, etc.). This mode represents the anti-globalisation and anti-capitalist face of the GJM, which is negatively oriented against the symbols, processes, and impacts of economic globalisation [cf. Starr 2000; Ruggiero 2002; Seohane and Taddei 2002; Crossley 2003; Wilkin 2003; Buttel and Gould 2004; Fernandez 2008]. Another mode of GJM activism is represented by the social-fora process (the World Social Forum - WSF, and the European Social Forum - ESF) that involves series of mass conferences by social groups, networks, and organisations to discuss various issues of global and political importance and shape practical strategies to address them. This began in 2001 and continues to take place on the global, continental (regional), national, and local levels, and it embodies institutionalised and progressive efforts to develop a widely shared vision of alternative global development. In other words, this mode stands for a more constructive (positive, creative) movement for a globalisation from below or for global justice [cf. Aguiton et al. 2003; Kolb 2005; Della Porta, Peterson and Reiter 2006; Giugni, Bandler and Eggert 2006; Della Porta 2007; Smith 2008; Staggenborg 2008].

Naturally, the two modes are not mutually exclusive or isolated from each 
other: mass street protests are often preceded by sophisticated ideological and symbolic activities, and social fora are sometimes accompanied by mass demonstrations and street gatherings that can turn violent. Although some have viewed these two modes as evolutionary stages in the development of the GJM, that is, a progression from refusal towards formulating an alternative [Ayres 2005; Held and McGrew 2007: 202; Hosseini 2010: 63-65], it is probably more appropriate to grasp them as equally important expressions of the movement [Pianta 2001; Giugni, Bandler and Eggert 2006: 3, 6-7; Pianta and Marchetti 2007: 40; Smith 2008: 99] whose relevance changes over time. Nonetheless, identifying these basic modes of operation may allow us to formulate a working (meso-level) definition of the GJM as an interacting network of organisations and groups with a collectively shared alter-globalist identity that backs up the series of mass protest mobilisations and/ or social fora against transnational neoliberal policies and institutions. ${ }^{1}$

Although it is still relevant to analyse the static GJM attributes, it is its dynamics that have recently become the most challenging area of study. One of the key questions here concerns the overall evolution of the movement and builds upon the study of mass GJM mobilisations and their attendance, or the evolving numbers of GJM actors in various countries or regions. These different operationalisations also produce different conclusions - we are told either of the rise of the movement [cf. Pianta 2001, 2005] or of its weakening and decline [cf. Podobnik 2005: 57; Curran 2006; Paczynska 2008].

The explanations for these trends vary, but the most prominent hypotheses build empirically upon the consequences of the 'War on Terror' and the subsequent rise of mass mobilisations against the wars in Afghanistan and Iraq, and are theoretically grounded in the concept of social movement spillover [Meyer and Whittier 1994; Whittier 2005]. This set of hypotheses contains two perspectives. According to the first of them, there has been a process of mutual exchange or penetration between the GJ and anti-war movements that has essentially influenced the development of the former. This hypothesis deploys the concept of spillover in its original sense as a process of mutual influence and support between two or more separate movements - i.e. the material, human, or symbolic resources spill over from one movement into another, or relevant opportunities are shaped by one movement for another. In the context of the GJ and anti-war movements the focus is on the spillover of supporters, activists, and resources between the two [cf. Bennett 2005; Della Porta and Tarrow 2005: 227-228; Tarrow 2005: 16-17; Fisher 2007].

The second perspective builds upon the study of the GJM development in the United States, which produced an alternative spillout hypothesis [Hadden and

\footnotetext{
${ }^{1}$ Donatella Della Porta provides a similar definition of the GJM: '[a] loose network of organisations (...) and other actors engaged in collective action of various kinds, on the basis of the shared goal of advancing the cause of justice (...) among and between peoples across the globe' and 'participating in protest campaigns on the issue of global justice' [Della Porta 2007: 6-8].
} 
Tarrow 2007]. This is basically inspired by the spillover concept but replaces the optimistic idea of mutual enrichment between GJM and anti-war activism with the notion of 'the hollowing-out of a social movement when its activists shift their activities to a cognate, but differently structured, movement' [Hadden and Tarrow 2007: 360]. In other words, spillout is understood here as the impoverishing of a social movement when its activists shift their activities (resources, ties, contacts, etc.) to a more or less affinitive but thematically or organisationally different movement, resulting in the depletion and consequent demise of the former [ibid.].

As I appreciate the analytical potential of the spillover/spillout concepts, I want to introduce them in more detail, review them in light of other key research frameworks focusing on social movement dynamics, and identify their most analytically advantageous aspects.

\section{Two models of movement dynamics: spillover and spillout}

The spillover perspective obviously reflects, on the one hand, the continuing efforts to capture the dynamics of social movements and, on the other hand, a rejection of the perception of social movements as entities isolated from their environment. Students of spillover processes situate this concept within the broader realm of movement-movement interactions and subsequently understand them as the problem of movement-movement influence (or effect) [Meyer and Whittier 1994; Whittier 2005]. In this context, the spillover effect of movements (altering the form of other protests) is differentiated from their generative effect (creating new challenges or a new overall level of protest) [Whittier 2005: 533].

The spillover concept is empirically based on a case study of the interaction between the women's and the peace movement in the United States and theoretically refers to political process approaches and to the New Social Movement theory [cf. Meyer and Whittier 1994: 278]. The use of these theoretical traditions makes the analytical focus of the spillover approach somewhat indirect or mediated. First, both of them assume that there is a certain distance or gap between two or more actors that is bridged by various channels and mechanisms. In the model of social movement continuity (inspired by the New Social Movement perspective) this gap is represented diachronically and lies between a movement's vanishing and successive movement(s), while in the model of social movement outcomes (stemming from the political process theory) the gap is synchronic as there are clearly two or more parallel and separate movements that influence each other. Second, the spillover effect is conceptualised as a diffusion of particular characteristics between movements [Whittier 2005: 536]. More specifically, this process is conceptualised as a social movement outcome and is studied both at the level of the political and cultural environment, and at the level of the movement itself (its personnel, organisation, and norms). These are considered to be the key areas of intermediation between movements. The actual outcomes, or effects, of one movement's influence on another are sought and evaluated within 
four dimensions of the movement's existence and activity, i.e. in its ideological frames ${ }^{2}$ (movement culture, collective identity), tactical repertoires, organisational structure, and leadership [Meyer and Whittier 1994: 286; Whittier 2005: 536].

To make their spillover concept more dynamic Meyer and Whittier propose four potential routes of influence or 'structuring mechanisms' through which one movement influences another [Meyer and Whittier 1994: 290; Whittier 2005: 541-548]. The first one, 'coalitions' (organisational networking), brings social movements into contact and enables them to share and receive different aspects of their activities. The second one is the 'social movement community' $\left(\right.$ or sector ${ }^{3}$ ) and denotes a cultural environment that mediates the transmission of less formal and softer aspects of activism, such as norms and values. The third one is 'personnel' (or activist biographies), which involves the exchange or sharing of individuals and the consequent changing of micro-level features of a movement's activities. Finally, the 'political opportunity structure' is cited as the means by which one movement may shape the activity or even the existence of another one through the transformation of its external political and cultural contexts.

The discussion below draws on other relevant conceptual frameworks of social movement research. First, and most importantly, the spillover perspective has been repeatedly criticised (1) because of its alleged neglect of the negative consequences (losses) stemming from the interaction of two or more collective actors, and (2) because it ignores the overall transformation of the interacting movements in favour of partial effects analyses. Thus, the spillout concept has been formulated [Hadden and Tarrow 2007] in order to capture both the costs of movement-movement interaction, but also - more notably though less explicitly - the overall immediate transformations of the single movement responding to its environment (whether that means another movement, a field of activism, or the political institutions of the state). So there is an analytical shift from determining the channels of influence among the movement and other actors and assessing the impacts of mediated interaction caused by these actors towards the dynamics of a single movement in terms of identifying the immediate and conscious (strategic) transfer of its structural and symbolical properties into a thematically different movement or field of activism. In other words, the spillout perspective - while still building upon original Meyer's and Whittier's concept - moves the analytical focus away from the outcomes of mediated movement-movement interaction more towards the content of single movement evolution.

\footnotetext{
${ }^{2}$ Frames of (collective) action denote the interpretative schemes that enable individuals to 'locate, perceive, identify, and label occurrences within their life space and the world at large'. By assigning meaning to these phenomena, these schemes condition and shape (collective) action [cf. Snow et al. 1986: 464].

${ }^{3}$ In this article, the social movement 'sector' is understood as thematically defined clusters of social movements and their organisations (women's movement sector, peace movement sector, etc.).
} 
Second, I follow the widely shared definition of a social movement [Della Porta and Diani 2006: 20]. Here I understand the key dimensions of a social movement as its conflictual relations with its opponents, its (informal) networking, and its distinct collective identity. I consider these to be critical for a social movement's existence and consequently also for the meso-level study of the processes whereby such a movement flourishes or declines in one area of contention and/or migrates into a thematically different one. In contrast to Hadden's and Tarrow's study of the spillout of the GJM into anti-war activism in the US, ${ }^{4}$ I empirically analyse public protest events and their framing within a given period in both the original (global justice) and an alternative (anti-war) area of contention, the coalitions and networks that existed during these events, and finally the collective self-identification of a particular movement. Compared to the original spillover study, I am not directly interested in the causes of the spillover process. Instead, I aim to select and identify some of the 'structuring mechanisms' that influence a movement (organisational networking) and the potential target areas of this influence (collective identity, framing), and treat them all as key properties in the evaluation of a movement's thematic shift.

Third, I treat both the social movement and its interactions with its environment primarily as a one multi-dimensional process and conceive it in terms of the mechanism-process approach recently formulated in studies of contentious politics [McAdam, Tarrow and Tilly 2001; Tilly and Tarrow 2007]. Thus, I expect that (1) this process is composed of combinations and sequences of mechanisms - or sub-processes - that produce certain outcome [Tilly and Tarrow 2007: 29], and that (2) these mechanisms follow identical or closely similar patterns across a variety of situations [McAdam, Tarrow and Tilly 2001: 25]. Consequently, the particular dimensions of the spillover process (as determined in the definition of a social movement) may be grasped as chains of various constantly operating mechanisms (or sub-processes) that have already been identified in other areas of political contention (for a brief overview of these see the list in Tilly and Tarrow [2007: 214-217]).

Fourth, and in conformity with Hadden's and Tarrow's perspective, I understand the social movement spillout more as one of a number of possible stages or outcomes of a social movement's spillover than as the process of movementenvironment interaction in itself. Although Hadden and Tarrow term the spillout as a process or a shift, they also state: '(...) what seemed like a dynamic "social movement spillover" evolved into a spillout of American activists into domestic politics' [ibid. 2007: 371]. Therefore, here I consider a spillout to be the effect of extreme spillover, which is only diagnosed once the spillover sub-processes within all the key dimensions of a social movement have occurred intensively, i.e. when

\footnotetext{
${ }^{4}$ This study focuses only on the original - global justice - issue area and demonstrates the spillout process on the number and forms of GJM protests, the strength of GJM coalitions in the US over time, and the degree of internalisation of global organising models [Hadden and Tarrow 2007: 362].
} 
all of a social movement's essential features have shifted away from the original area of activism.

My empirical assessment of the social movement spillover focuses on the varying extent to which a movement's public activities and how they are framed and/or its cooperative ties and/or its collective identity systematically and invariably shift to a new and thematically different arena(s) of political contention. ${ }^{5}$ I identify social movement spillout as having occurred once all these properties have jointly and thoroughly migrated to the new thematic arena and have deserted the original one. To this end, I trace the evolution of the framing and the issues of its public protest activities, the selection of partners and networks in its inter-organisational cooperation, and its expression of collective identity, and thus demonstrate the significance of the thematic shift. Consequently, the social movement spillout is identified as having occurred once all the processes of the migration from one issue to another have been accomplished.

\section{Data and measurement}

Given that the focus is on the meso-level analysis of the spillover/spillout of Czech GJM into anti-war activism, I concentrate primarily on the dynamics in these fields of contention and take social movement organisations and protest events as the main units of analysis. I am interested in tracing the processes of change of three key properties: how the participation in public protest events is framed, networking patterns and coalitions of 'social movement organisations' (SMO), and the collective identity of global justice SMOs. To be clear about the target area of the GJM spillover/spillout, it is also necessary to define the field of anti-war activism. In addition to the definition of GJM (see above), we add the definition of the anti-war activism as the public protest activities of a set of groups that have emerged on the eve of the second war in Iraq (2003) in the Czech Republic.

The study uses two types of original data. The first are the global justice and anti-war protest events between early 2003 (when the first public anti-war protests occurred) and early 2009. The protest events analysis is used to capture two key aspects of SMO existence relevant for tracing the spillover process: the framing of public protest activities, and the inter-organisational networking during these events (either through co-organisation of events or through the group's participation in the event; see Figures 1 and 2). Only clearly distinguishable public protest events were selected (i.e. demonstrations, happenings, performances, gatherings, or marches). These events were identified through a detailed analysis of global justice and anti-war actors' web calendars and official and independent media reports between January 2003 and February 2009. A total of 114 events

\footnotetext{
${ }^{5}$ I am not tracing, for example, the movement of the repertoire of action, personnel, or resources, as I consider these to be of secondary importance in the exploration of the thematic shift from one area of activism to another.
} 
were recorded, mostly in the form of street demonstrations (66 events), happenings (37 events), a combination of the two (6 events) or some other events (street parties, marches, concerts, etc.). Attendance for 53 events was recorded; the average attendance was 550 persons per event. The network (coalition) of SMOs for a single event was identified as all the groups that organised or participated in the event. The overall framing of the event was interpreted from available information related to the event (slogans on banners, interviews with participants, activist articles). Both the analysis of SMO networks and the interpretation of the overall framing of protest events are divided into two periods (2003-2006, 2006-2009) according to the development of the structure of political opportunities (see below). Furthermore, the date of the event, the number of participants (calculated as the average of the attendance figures reported by various media), and the repertoire were recorded.

Another data source (covering the collective identity aspect of Czech global justice SMOs) is a survey of 220 Czech SMOs conducted between October 2007 and October 2009. ${ }^{6}$ Group representatives were asked to fill out a questionnaire on the essential aspects of their group's activities, strategies, and structure. The questionnaire consisted of both closed and open-ended questions. The final sample of organisations was created by the snow-ball method, starting with the most important groups within various thematic sectors (expert estimation). The very GJM snowball started with organisations that were historically the most active in global justice activities. These were asked to choose among several possible labels for their own group and to name groups belonging to the Czech GJM. In the end, there were two lists: 24 groups that labelled themselves as alter-globalist, and 28 groups that were labelled as alter-globalist at least twice by other groups (out of these 28 groups, 2 had ceased to function at the time of the survey and 2 did not wish to participate in the survey). These two lists were compared and from them 18 groups that had both explicitly labelled themselves as alter-globalists and had also been identified as alter-globalist by at least 2 other alter-globalist SMOs were selected. The data used in Table 1 (see below) are based on the following questions (which are different from the snowball question): 'Does your group consider itself as part of some social movement? If yes, please name which one', and 'Which issue areas is your group dealing with? Please rank the three most important of them'.

\section{The process and the outcome of the GJM spillover: the Czech case}

To describe and evaluate the process of the GJM spillover/spillout into anti-war activism in the Czech Republic a detailed examination of this process needs to be carried out. As stated above, while the spillover process was originally conceived

\footnotetext{
${ }^{6}$ Czech SMO Survey (2007-2009). Conducted by the Institute for Comparative Political Research at the Faculty of Social Studies, Masaryk University in Brno. See http://ispo.fss. muni.cz/zajmy (retrieved 17 December 2010).
} 
as an indirect (mediated) movement-movement influence, the way this process is understood in this article is strongly inspired by the Hadden's and Tarrow's focus on the simple shift of the issues and framing of the movement's public activities, its allies and coalitions, and its collective identity to another, thematically different area of activism. I am particularly interested in the progress of the spillover processes in three key dimensions of the Czech GJM.

\section{The structure of the Czech GJM: key currents and actors}

My analysis is based on the assumption that it is possible to clearly identify a global justice movement in the Czech Republic. Based on the working definition of the GJM established above, earlier research in the field [Císař and Slačálek 2007; Kolářová 2009], and my own data, I argue that an interacting activist network sharing the general goals and identity of transnational GJM has continued to exist in the Czech Republic. Like in the Western context, most of the GJM actors had existed before the rise of the movement in the late 1990s and later. Two main types of subjects were part of this movement from its very beginning. ${ }^{7}$ These types were characterised by their political-ideological engagement and themes of action. The first and core type consists of radical anti-capitalist groups. The second, much less common, and more fluctuating type includes religious groups and NGOs oriented towards environmental issues and human rights. It is primarily the dominance of the former type of actors within the Czech movement that makes the movement so very internally fragmented but at the same time has enabled it to wholly and smoothly absorb a newly established alter-globalist identity. No other collective identification or issue (e.g. peace, environmental issues, human rights protection) was significant or enduring enough or even shared by these actors to serve as a basis for engaging them in lasting cooperation: such ties of cooperation and identity among all key members of the Czech GJM only became simultaneously activated during the coordination of several countrywide or even transnational global justice events that these actors jointly participated in. Therefore, I characterise the Czech global justice movement as being primarily composed of radical-left groups that cluster into several ideological currents.

The ideological fragmentation of post-communist Czech society and its general animosity towards leftwing ideologies and political radicalism made it impossible for the Czech GJM to successfully raise the issue of capitalist globalisation, to mobilise wider public opinion or action, to cooperate, network and build enduring operational coalitions, and to share resources or personnel. The anti-capitalist core of the Czech GJM is dominated by three ideologically autonomous and organisationally heterogeneous currents, whose mutual relations have

\footnotetext{
7 These may also be paralleled with anti-capitalist and eco-pacific sectors within West European GJM identified by Della Porta, Peterson and Reiter [2006: 31-43]. There is no 'anti-neoliberalist left' in the Czech Republic.
} 
always determined both its overall dynamics and outcomes [cf. Bastl 2001; Císař and Slačálek 2007; Kolářová 2009].

The first of them consists of the anarchists. The contemporary anarchist movement originated in the final years of the old regime, and it has always displayed the strongest degree of internal fragmentation. Its founding motive is its hostility towards authoritarian and paternalistic political ideologies and actors, which obviously limits the possibilities for cooperation with other currents of the Czech radical left (namely with the communists). The process of integration and networking among anarchist groups and activists culminated in the mid1990s with the establishment of this current's main platform, the Czechoslovak Anarchist Federation (Československá anarchistická federace - ČSAF). Both the individualistic and autonomy-oriented tendencies associated with squatting and music subcultures and the more economically oriented and collectivist-syndicalist tendencies co-existed under this platform [Bastl 2001: 38-40; Kolářová 2008: 4]. The main syndicalist currents separated in 1996 to form the Organisation of Revolutionary Anarchists (Organizace revolučních anarchistů Solidarita - ORAS) and then in 1997 the Federation of Social Anarchists (Federace sociálních anarchistů FSA). The former experienced some success, but ceased to exist after a few years. The anti-fascist platform is represented by Anti-fascist Action (Antifašistická akce - AFA), which emerged in 1996. Another important GJM group is the activist network associated with the key anarchist journals Autonomy (later renamed Confrontation) and the most important media project of Czech anarchism A-kontra [Císař and Slačálek 2007: 5-6]. Second, there are the Food Not Bombs (FNB) initiative, and the Feminist Group of 8th March (Feministická skupina 8. března - FS8), both of which are associated with autonomist anarchism and with the ČSAF [Bastl 2001: 71-73]. In 2004, the largest regional platform Protestfest, tied to lifestyle anarchism and alternative culture, was founded in Brno, the Czech Republic's second largest city.

The second ideologically consistent current within the Czech GJM is represented by the Trotskyist and revolutionary socialist organisations, and by four of them in particular. The first and oldest is the Socialist Alternative Future (Socialistická alternativa Budoucnost - SAB), which is a member of the international Committee for a Workers' International, has some linkages to the anarchist current, and for some time was associated with the Communist Youth Union (Komunistický svaz mládeže - KSM, see below) [Bastl 2001: 76-77]. The second important Trotskyist organisation, Socialist Solidarity (Socialistická Solidarita - SocSol), was founded in 1990. The third dominant Trotskyist organisation, the Socialist Organisation of Workers (Socialistická organizace pracujících - SOP), emerged in 1998 as a group of radicals that had split from SocSol and defined itself as revolutionary Marxist [Bastl 2001: 96]. The SOP maintains probably the most orthodox Trotskyist position and simultaneously takes the most positive stance towards cooperating with the communist current. This also stems from the SOP's previous campaigns against sweatshops, drug repression, and racism, which were supported by the communist youth and SocSol. The Group of Revolutionary Youth (Skupina 
revoluční mládeže - REVO) was founded in 2000 as the SOP's youth organisation, and has concentrated on organising young anti-capitalists. Outside the existing Trotskyist structures there is another (unorthodox) Marxist group engaged in GJM activism called the Socialist Circle (Socialistický kruh - SOK), which is mostly oriented towards intellectual and analytical activities.

The last of the three key radical currents in the Czech GJM are the communists, represented mainly by the Communist Party of Bohemia and Moravia, the Communist Youth Union, and several other groups. The KSČM was founded in 1990 and has been continuously represented in Parliament since 1990. The KSČM declares itself to be a democratic socialist party, and also identifies itself with the traditions of the communist movement [cf. Hanley 2001; Kunštát 2004; March and Mudde 2005]. Its activities and influence in the Czech GJM are often indirect, involving the provision of material and organisational resources to other subjects [Bastl 2001]. It also has personnel ties to some key present projects in the movement, such as the Initiative for Social Fora (Iniciativa za sociální fóra - ISF), the Czech branch of United for Intercultural Action - Duha United (UNITED), or with the Society for European Dialogue (Společnost pro evropský dialog - SED). Another (non-parliamentary) party in the GJM is the Party of Democratic Socialism (Strana demokratického socialismu - SDS), which has close ties with KSČM as it emerged out of one of KSČM's split-off groups. The KSČM youth organisation, KSM, was also founded in 1990, and was soon taken over by a group of members defending Leninist orthodoxy. In October 2006 the organisation was banned by the Ministry of Internal Affairs as anti-systemic, ${ }^{8}$ but it is still active and transforming itself into new organisations. In contrast to other organisations affiliated with the KSČM (such as Trades Union of Bohemia, Moravia and Silesia / Odborové sdružení Čech, Moravy a Slezka - OSČMS) and minor groups (Club of the Czech Borderland, Leftist Club of Women, etc.), the KSM's global justice activism seems to be the most consistent and publicly oriented.

The second main type of organisations active in the GJM has had less stable ties with this sector of activism over time. In the late 1990s there were several radical environmental groups participating in GJM activities. These were namely Earth First! (EF!), the Rainbow Movement - Friends of the Earth Czech Republic (HD), the Independent Social-ecological Movement (Nezávislé sociálně ekonomické hnutí - NESEHNUTÍ), and Children of the Earth (Děti Země - DZ). Some of these groups have transformed themselves into standard project-seeking and professionalised NGOs since then (NESEHNUTÍ, DZ, and HD), or are no longer active anymore (EF!). Greenpeace Czech Republic is widely perceived as the key actor in this branch of the movement, but the organisation itself rejects

8 The KSM was accused of breaking the law of public assembly by pursuing political activities and spreading 'class hatred' through their advocacy of Marxist and Leninist political philosophy. See 'First Letter from the Czech Ministry of the Interior to the Communist Youth Union', 25 November 2005. Retrieved 6 January 2009 (http://www.blisty. cz/files/2006/ksm/20051127_mvcr-benesova-vyzva.pdf). 
the alter-globalist identity (as do DZ and HD). Religious groups are represented by the Ecumenical Academy (Ekumenická akademie - EA), which focuses on development aid and Third World debt, the Movement for a Just Society and Fellow Feeling (Hnutí za spravedlivou společnost a lásku k bližnímu - HSSLB), and by Christian Dialogue (Křestanský dialog - KD). There is also the Humanist Movement (Humanistické hnutí - HH), which encompasses a religiously-oriented network of groups, NGOs, and one political party. HH emerged in 1994 and focuses on issues of human rights and Third World development and also identifies itself with the alter-globalist vision while maintaining strict distance from the rest of the Czech GJM. Since 2003 it has started to accentuate the traditions of non-violence and has re-oriented itself towards anti-war activism. The last group of the second current consists of human rights and development NGOs, such as the Society for Fair Trade (Společnost pro Fair Trade), Trust for Economics and Society (Trast pro ekonomiku a společnost), Glopolis or People in Need (Člověk v tísni). Although these actors explicitly endorse a collective alter-globalist identity, they basically do not participate in domestic GJM/anti-war public protest activities.

\section{The evolution of the Czech GJM to 2002}

The very first GJM protest events in the Czech Republic were organised by networks of autonomist-anarchist and radical environmental groups (Confrontation, squatting communities, ČSAF and other anarchist cells, EF!) that have gradually internalised the emerging symbolic frames of the Western GJM. These frames were built upon resistance against the particular consequences and local impacts of economic globalisation, while the general critique of the political economy of globalisation remained somewhat neglected or unspoken during this period [Kolářová 2008: 4; Růžička 2007: 37]. The main events with GJM framing were the street parties that started in 1998 and were inspired by the activities of the People's Global action (PGA), Reclaim the Streets, and other Western SMOs and networks [cf. Císař and Slačálek 2007: 2]. These groups mainly mobilised themselves around the environmental and cultural issues of urbanism and motorism, and only indirectly addressed anti-capitalist and anti-globalist issues. ${ }^{9}$

The first and predominantly anti-capitalist stage of the movement's evolution culminated in September 2000 during the IMF/WB summit in Prague. The

\footnotetext{
9 The largest street parties took place in 1998 and 2000 with, respectively, 2000 and 5000 participants. Common slogans included 'The streets for the people', 'Rescue the city' or 'The Earth does not belong to man, man belongs to the Earth'. See, for example, 'Party Reports. Street Party'. Techno.cz. Retrieved 6 January 2009 (http://www.techno.cz/party/ report/1999/sp-o.htm). In the post-communist settings this may be considered an obvious success that has only been surpassed once since then; other similar events in 2000-2002 never succeeded in surpassing these attendance figures [Císař and Slačálek 2007: 2]. The ban on the part was revoked by the court in January 2010.
} 
preparatory activities began in mid-1999, and the event itself was the most successful moment in the history of the Czech GJM, ${ }^{10}$ in terms of both the number of people (estimated at between ten and twelve thousands) who were mobilised explicitly on issues of anti-corporatism and against the political symbols of economic globalisation, ${ }^{11}$ and its ability to interconnect traditionally fragmented domestic subjects and integrate them into transnational GJM networks [Welsh 2004]. In March 2000 the preparatory activities led to the formation of an unprecedentedly broad organising coalition to coordinate the protests, the Initiative Against Economic Globalisation (Iniciativa proti ekonomické globalizaci - INPEG). INPEG consisted of key anarchist groups (ČSAF, ORAS, AFA, A-kontra, and FNB), some Trotskyist subjects (SocSol, SAB), and radical environmentalists (DZ, NESEHNUTÍ, EF!) [Slačálek 2000]. Both the activities and the profile of INPEG were closely tied to the anarchist tradition and it declared itself an 'anti-authoritarian platform' and consequently did not allow any Trotskyist (SOP) or communist (KSM) groups to participate in it. In September 1999 these groups (SOP, SAB ${ }^{12}$ REVO, KSM, OSČMS, UNITED) and the Christian HSSLB launched a 'Stop the IMF!' platform, which was built upon a predominantly Marxist and Leninist framing of the protests. Both platforms ran their campaigns concurrently, but the organisers of the latter campaign ultimately supported the events organised by INPEG. Both platforms networked with the international GJM - INPEG coordinated activities with PGA, Indymedia, and ad hoc organising groups, while 'Stop the IMF!' interacted mainly with the foreign counterparts of its members (socialist and communist parties and trade unions, UNITED, etc.). ${ }^{13}$

While 'Stop the IMF!' was from the outset considered to be a temporary project, running just for the duration of the summit protests, INPEG continued to exist for a few months after the protests were over. It then gradually declined after internal disputes broke over conflicting appraisals of the members' activities

\footnotetext{
${ }_{10}$ This fact, however, was largely the result of the transnational dimension of this event, which makes it difficult to compare it to other Czech global justice events in terms of key attributes (repertoire, attendance, media coverage, etc.).

${ }^{11}$ Among the main statements were 'Stop the IMF', 'Cancel Third World Debt', and 'Prague, Seattle and What Next? We Will Dispossess the Capital'. See 'Protesty v ulicích Prahy skončily bez násilí.' (Protests in the Streets of Prague Ended without Violence) Mf Dnes, 23 November 2000. Retrieved 6 January 2009 (http://zpravy.idnes.cz/protestyv-ulicich-prahy-skoncily-bez-nasili-fnh-/domaci.asp?c=A000923131544domaci_itu).

12 The SAB participated in both platforms, but was criticised for its passivity in the former and left the latter before the main event. See 'Antikapitalistické hnutí: Seattle, Praha a co dál... (The Anti-capitalist Movement: Seattle, Prague, What Next...) Socialistická Solidarita 9: 10-11. Retrieved 6 January 2009 (http://sop.revoluce.info/download.php?6cf921ab421a b9413f627d6d9b7e492b).

${ }_{13}$ There were also several minor projects run by other groups during the summit. The CEE Bankwatch Network ran seminars and workshops and together with EA and HD organised a discussion forum. $\mathrm{HH}$ and its foreign branches organised a separate Festival of Humanism.
} 
during the protests (especially between ČSAF and SocSol) and after the platform's ability to find a common position was questioned by the anarchists [Slačálek 2000]. In spite of this, INPEG marked an important turning point in the development of the Czech GJM. This is because, first of all, it fundamentally enhanced both existing and new networking patterns within and across its main currents: the ties between the Trotskyists (SOP, SocSol) and autonomist anarchists (ČSAF, ORAS) deepened, tensions between autonomists and syndicalists (FSA) were eased, and communication between the autonomist anarchists and Trotskyists (SocSol) was established. And second, it simultaneously helped to establish an anti-globalisation frame by raising the issue of the general political economy of globalisation.

\section{The moment of transition: the NATO summit in 2002}

After 2001 the international and domestic structure of political opportunities started to change and the alter-globalisation movement entered its next stage. During this time, several interconnected processes occurred that signalled the existence of a need, willingness, and capacity for spillover outside the field of GJM activism: first, the movement's ability to mobilise on global justice issues sharply declined; ${ }^{14}$ second, there was an easy and prompt shift in emphasis from the issues of capitalist globalisation more towards war/militarism. This frame bridging ${ }^{15}$ clearly emerged for the first time during the protests at the NATO summit in Prague in November 2002. ${ }^{16}$ Third, some of the networking patterns that had spread and grown in 1999 and 2000 basically retreated, but at the same time new ties were brokered between the GJM and other sectors of activism. ${ }^{17}$

The NATO summit separately activated all the key organisational components of the movement with the exception of the green NGOs. Anarchists, Trotskyists, and communists still framed their protests in 'traditional' anti-capitalist rhetoric, but they at the same time intensified their criticism of the militarism and

14 The Prague street parties run by anarchists in 2001 and 2002 attracted only around 500 participants; in Brno the numbers declined from some 700 people in 2001 to around 500 people in 2002.

${ }_{15}$ The mechanism of frame bridging in collective action is defined as the linkage of two or more ideologically congruent but structurally unconnected frames regarding a particular issue or problem' [Snow et al. 1986: 467].

16 This is well illustrated in the statement of one demonstrator: 'We are non-violently demonstrating here against militarist NATO and against the rich. It's an anti-global demo. NATO has already killed $x$ thousands of people and we want to express our disagreement (...)'. See 'Pískalo se, bubnovalo, tancovalo a jedlo (There was whistling, drumming, dancing, and eating) Radio Praha, 21 November 2002. Retrieved 6 January 2009 (http://www. radio.cz/cz/clanek/34745).

${ }_{17}$ Within the context of the mechanism-process approach, brokerage is defined as connecting 'two previously unconnected social sites' and thereby lowering 'the cost of communication and coordination between them' [Tilly and Tarrow 2007: 206]. 
imperialism of George W. Bush's administration. The anarchists (namely ČSAF, FS8, FNB, and ORAS) established a single-issue antiNATO platform. Their activities were organised both in Prague and Brno (ORAS, AFA), and consisted of demonstrations under the slogans 'against NATO and capitalism' and 'to abolish wars means to abolish the state and capitalism'. Communists represented by the KSČM concentrated both on the demonstrations and on organising their own counter-conference. Their demonstrations were directed against American imperialism and NATO as a 'threat to world peace', while around 150 representatives from European socialist and communist parties attended the counter-conference focused on alternative European security architecture. The Trotskyist groups (REVO, SocSol) held the smallest demonstration with open anti-capitalist and anti-militarist slogans.

Despite the overall decline in the movement's brokering capabilities after 2000, there were two important shifts in networking patterns in 2002. First, while the anarchist platform concentrated on organising the activities of ideologically affiliated groups, the Trotskyists (SocSol) launched a more ambitious project called Initiative Against the War (Iniciativa proti válce IPV) aimed at coordinating the direct action of various global justice and peace groups and transnational movements. The IPV was organised as a single issue campaign with an anti-war framing, and it was later joined by other Trotskyists (SOP, REVO) and by individual communist activists and student associations. Second, religious groups (particularly EA) became more independent and active in the public GJM and anti-war activities, and jointly organised a conference against NATO highlighting globalisation as a threat to world peace.

\section{Czech GJM activism after 2003}

After 2003, the radical-left core of the Czech GJM continued to follow its Western counterpart in organising public activities explicitly on GJM issues and within the GJM framing. These followed two parallel trajectories: the anarchists continued their anti-capitalist activities and maintained their organisational isolationism, and the Trotskyists and communists attempted to follow the social-fora process and build broad GJM coalitions with public support.

The anarchists have followed the 'classic' protest tradition - whether that means the kind of protests organised in support of the Zapatistas' struggle or the fight against global economic and political elites. The two most important global justice events of this type were: the demonstration of solidarity with the activists arrested during the G8 protests in Heiligendamm in June 2007 and the protests against repression during the NATO summit in Bucharest in April 2008. Since 2004, Protestfest in Brno has annually organised street parties with concerts and workshops under various central mottos and supported by local ČSAF and AFA groups and individuals from environmental NGOs. 
In January 2004 the non-anarchist currents jointly established a broad platform intended to coordinate Czech GJM activism with the international social fora process - the Initiative for Social Fora (ISF). The Trotskyists (SOP, REVO) and communists (KSČM, KSM) were the most instrumental in founding the ISF but some other groups participated as well: other Trotskyist groups (SocSol, SAB) and Marxists (e.g. SOK), Christians (HSSLB, EA, KD), extra-parliamentary parties (SDS, etc.), and individuals from ČSAF (which once again officially refused to cooperate with 'authoritarian' groups).

In September 2004 the ISF organised the first Czech social forum that identified itself with the WSF/ESF process and drew attendance from activists and representatives of major Czech left parliamentary parties (the ruling Social Democrats and KSČM). The programme consisted of three key links: wars, economic globalisation, and racism. The forum was attended by approximately 100 participants and generally viewed as a failure by its key organisers..$^{18}$ The next Czech social forum in October 2005 was framed in a slightly different manner: it was called the 'Revolt Forum' and attempted to combine the model of a classic activists' gathering (again raising the issues of war and economic globalisation, newly coupled with global climate change and a few national themes) with a street party targeting the younger generation. The third Czech social forum (and the last one within the period of this study) took place in March 2007 and followed a similar pattern of combining a conference with a street party. Nonetheless, this social forum differed in the degree to which it was integrated into the anti-war framing (see below): the timing, organisation, and main issue of the event were closely tied to anti-war and anti-base ${ }^{19}$ protests. The forum itself was preceded by a demonstration 'against wars, military bases, and racism', which once again exposed the existing tensions between the ISF and anti-war non-communist groups. In fact the whole forum consisted of one plenary session dedicated to the US government's intention of locating a military radar base in the Czech Republic, and two seminars on economic issues. After 2007, the ISF lost its strength as a platform for organising domestic events and instead transformed itself into a logistic tool for some communist, Trotskyist, and religious groups, enabling them to maintain or strengthen their international contacts. ${ }^{20}$

18 The SOP openly stated that the 'Czech social forum in 2004 with slightly over 100 participants was not successful. The organisers, including us, made a lot of mistakes.' See 'Jak dál pro České Sociální Fórum.' (Where to Now for the Czech Social Forum?) SOP website. Retrieved 6 January 2009 (http://sop.revoluce.info/index.php?id=9,47,0,0,1,0).

${ }_{19}$ The campaign against the US government's intention to locate a military radar base in the Czech Republic was launched in mid-2006; see below.

${ }^{20}$ All GJM currents concurrently participated in transnational GJM activities. Anarchists focused and participated in large protests and counter-summits (G8, NATO) but also in traditional cross-border projects with associated groups from Central-Eastern Europe (e.g. Poland or Slovakia). Other GJM groups (including communists) focused on the social-fora process, which has primarily been promoted by the ISF. 


\section{Czech anti-war activism 2003-2009}

The boom in anti-war activism corresponded mainly with the US preparations to go to war with Iraq during late 2002 and early 2003. Unlike in Western countries, there were basically no public Czech protests against the US invasion of Afghanistan. The evolution of Czech anti-war activism may be easily divided into two basic phases corresponding to the transformation of the national political context. The first of them lasted from January 2003 to July 2006 and was dominated

Figure 1. Czech antiwar events by organisers (January 2003-July 2006; N=37)

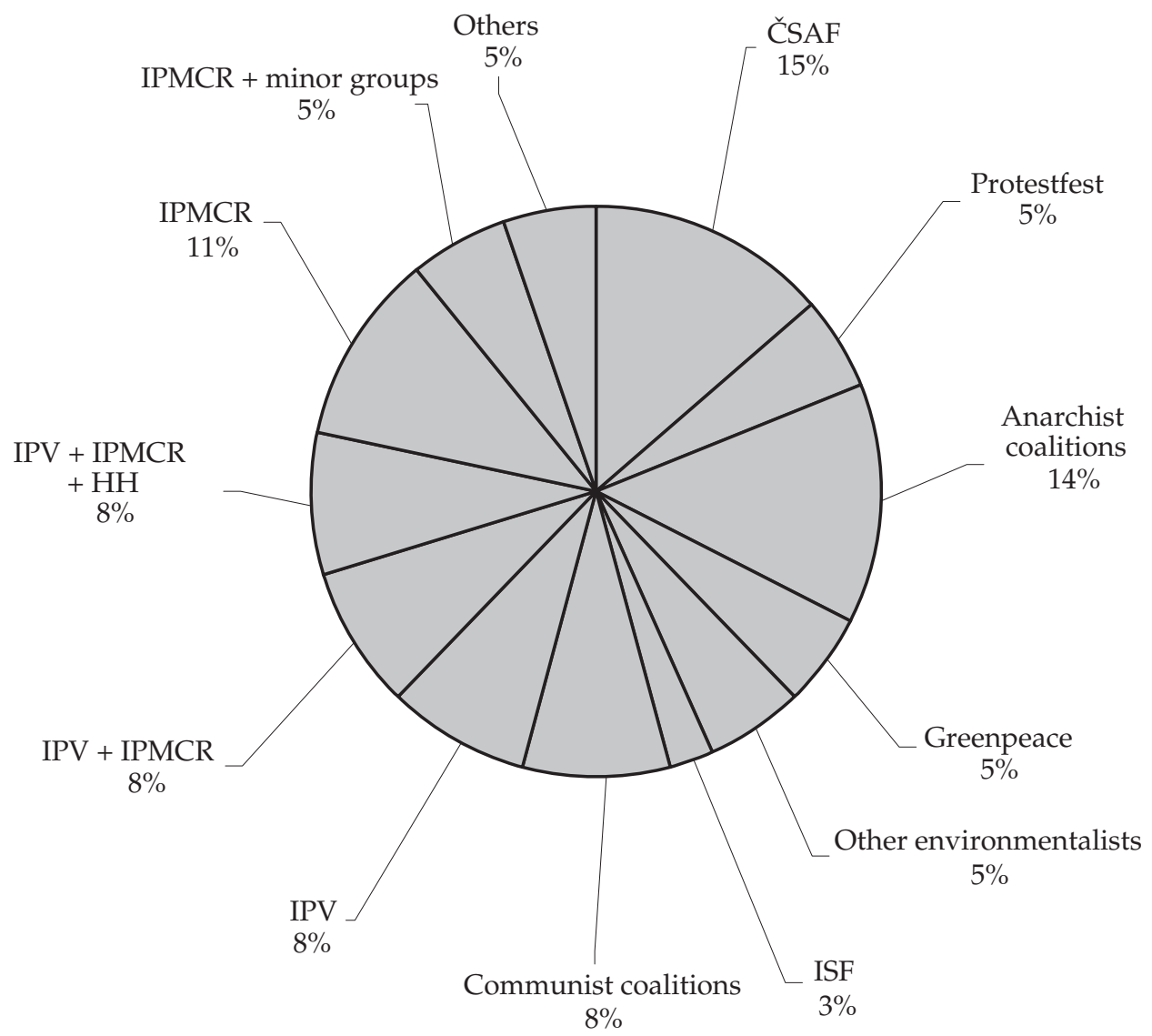

Source: Author.

Note: ČSAF - Czechoslovak Anarchist Federation, HH - Humanist Movement, INEZ

- NO to the Bases Initiative, IPMCR - International Peace Movement in the Czech Republic, IPV - Initiative Against the War, ISF - Initiative for Social Fora, KSČM - Communist Party of Bohemia and Moravia, KSM - Communist Youth Union. 
by the resistance to the war in Iraq and Afghanistan; the second started in August 2006 and consists of activism against the location of US military radar base in the Czech Republic.

Protest event analysis clearly suggests that GJM actors were dominant in organising and participating in the 'new' anti-war protests during the first stage (see Figure 1).

Out of a total of 37 anti-war public protest events during the previous stage of anti-war mobilisations, 19 (over 51\%) were exclusively organised by GJM actors and another 8 (about $22 \%$ ) were co-organised by them. Anti-war actors ran exclusively only 6 (over 16\%) and environmentalists 4 events (about $11 \%$ ). The most active group was the anarchist block (mainly ČSAF), which on its own coordinated 12 events and largely continued to distance itself from other ideological currents. ${ }^{21}$ Although the events organised by communists were less frequent (3 demonstrations coordinated by KSCM and KSM), one of them was the largest anti-war protest ever (2500 participants). Most importantly, the transformation of the networking patterns between various actors was initiated by the IPV, the $\mathrm{HH}$, and the International Peace Movement in the Czech Republic (IPMCR), which merged into a broad anti-war coalition. The IPMCR was formed on the eve of the Iraq war outside the GJM by liberally and environmentally oriented members of the American community in Prague and was one of the founding groups of the Czech anti-war movement (for a definition see the previous section). ${ }^{22}$ The group organised 4 protests by itself, co-organised 2 with minor peace groups, 3 with the IPV, and another 3 with the IPV and the $\mathrm{HH}$, averaging some 300 participants per event. Although the IPMCR decidedly rejected the option of including the communist organisations because of the latter's orthodox political mission, the coalition became the fundamental platform for the brokering the cooperation after mid-2006.

The framing of the 2003-2006 anti-war protests (at least those co-organised by the GJM actors) abandoned its formerly localised environmental and cultural perspectives and the emphasis shifted towards anti-war issues and rhetoric, but these were still explicitly matched with the concepts of global political economy, imperialism, and exploitation. The central motto of the 2003-2006 anti-war protests was 'No blood for oil', and resistance against the war in Iraq was closely tied to a critique of George W. Bush's foreign policy and particular oil corporations.

\footnotetext{
${ }^{21}$ Nonetheless, there was some shift in the strategy of the anarchists, which consisted of promoting non-anarchist protests and forming a clearly identifiable anarchist block within some protests organised by other sectors.

${ }^{22}$ A leading member of the IPMCR was also a founding member of American Voices Abroad (AVA), an international political organisation of expatriates in Europe that participated in anti-war activities after 2003. The IPMCR was not active before 2003. However, later it succeeded in brokering new alliances with other organisations of foreigners in Prague (e.g. Iraqi or Palestinian groups) and coordinating joint protest events.
} 
Figure 2. Czech antiwar events by organisers (August 2006-February 2009; N=77)

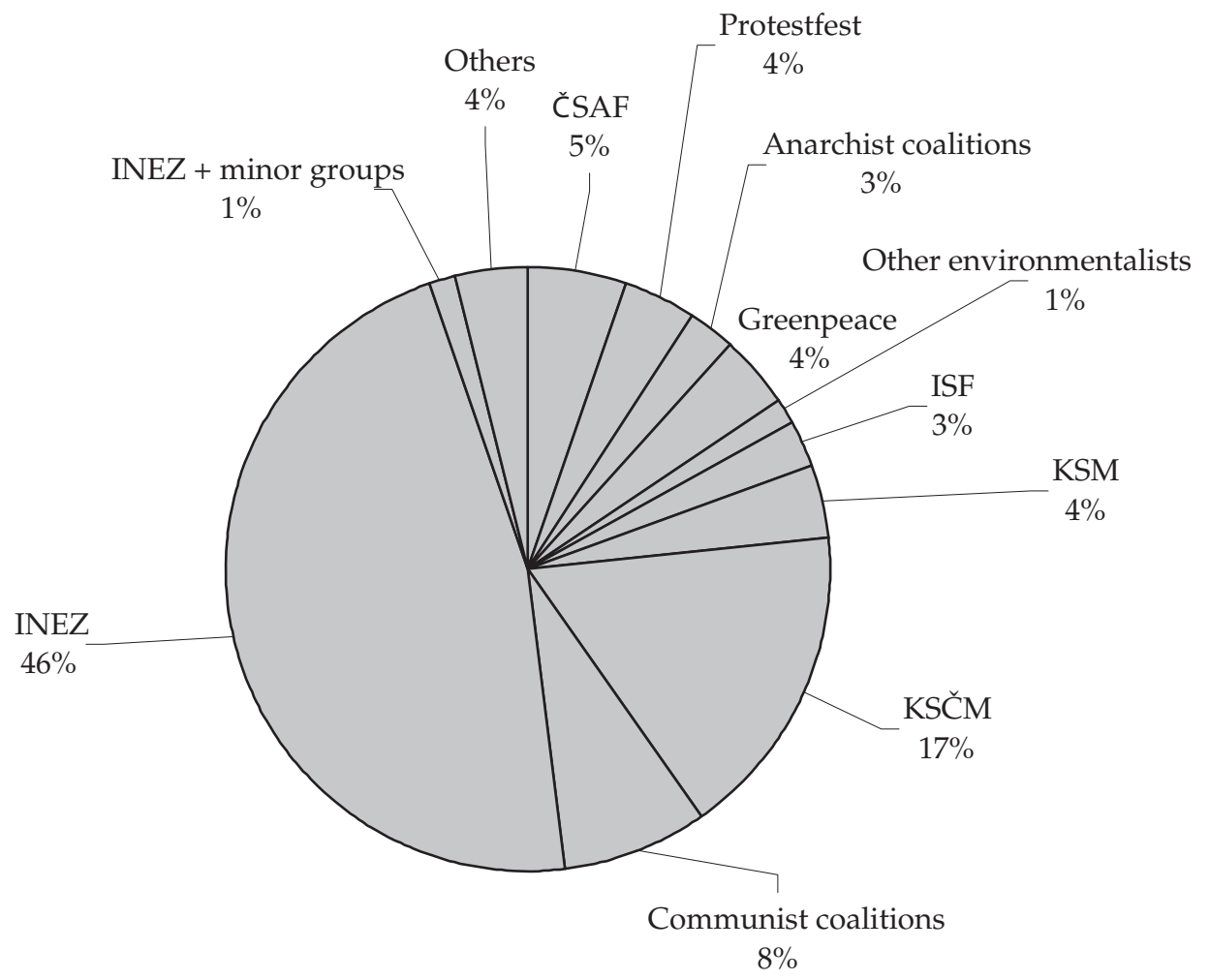

Source: Author.

Note: See Figure 1 above.

Crucial points that changed both the trajectory and the structure of the slightly fading anti-war activism ${ }^{23}$ were the negotiations between Czech and US officials over locating a US military radar base in the Czech Republic, which were made public in January 2006, the disclosure of the fact that US experts were already inspecting the site for this base in July 2006, and finally the official US request to the newly-established Czech centre-right government to join US National Missile Defense in January 2007.

In July and August 2006 the representatives of several GJM groups (SocSol, HH, SOK) formed a centrally-coordinated coalition that embraced most of the existing currents, groups and initiatives called 'NO to the Bases Initia-

${ }^{23}$ Altogether 25 out of 37 registered protest events of the first phase took place in 2003, 3 events in 2004, 3 events in 2005, and 6 events during the first six months of 2006. 
tive' (INEZ). ${ }^{24}$ It was joined by over 50 other groups and organisations, including key anti-war initiatives (IPV, IPMCR) and global justice SMOs. In addition to nonGJM anti-war groups (e.g. IPMCR), the whole Trotskyist current was included. The key difference between INEZ and former anti-war/GJM coalitions was the broader presence of environmentalists and especially the official inclusion of the communists (KSM). INEZ was also supported by the KSČM's satellite and allied groups. Although the KSM was withdrawn from the official list of INEZ supporters because of the ministry's ban (see above) and because of rising tensions with INEZ organisers, it has continued to informally coordinate its activities with the initiative. The environmental sector is represented by approximately 10 subjects including those with former GJM activities (NESEHNUTÍ, EF!). Another $10 \mathrm{mem}$ bers are religious groups (both Christian and Islamic) and groups also active in former anti-war and GJM events (namely EA, KD, HSSLB). Some green and feminist advocacy groups and some extra-parliamentary parties are also included. INEZ has thus formally linked - and is largely driven by - the key representatives of the Czech GJM, except for the anarchist block, which refused to participate because of the inclusion of 'authoritarian' organisations, but it nonetheless cooperates with and supports INEZ informally.

INEZ's protest campaign started in mid-2006. It is unprecedented in modern Czech history in terms of its endurance, public support, and number of mobilisations (see Figure 2).

Compared to the 37 public protest events organised by the previous antiwar activists between January 2003 and July 2006, 77 protest events against wars and the US military radar base were held between August 2006 and February 2009. Almost half of these events were organised or co-organised by INEZ (37 events), while the second most active was the KSČM and its satellites (24 events). The communist network supported INEZ, but also simultaneously coordinated its own protest campaign that - contrary to INEZ's - targeted mainly small cities and rural areas. The third key actor, the anarchists, by themselves organised 9 anti-war protests, but collectively (as the 'anarchist block') they have participated in some key INEZ-organised events or informally supported them. The largest protest was organised by the KSČM (2500 people) but INEZ also managed to mobilise between 1500 and 2000 participants at 5 of its biggest protests, thus exceeding by far the level of participation in the former anti-war (non-communist) protests..$^{25}$ The environmental groups (that on its own ran 4 events $^{26}$ ) - especially

\footnotetext{
${ }^{24}$ This step clearly fits into the conceptual scheme of the 'coalition formation' process or the mechanism that is defined as the 'creation of new, visible, and direct coordination of claims between two or more previously distinct actors' [Tilly and Tarrow 2007: 216].

${ }^{25}$ Both the communists (KSM) and INEZ also initiated their own petitions, and so far have obtained approximately 180000 and 170000 signatures, respectively

${ }_{26}$ The remaining three events were organised and co-organised by $\mathrm{HH}$ without INEZ, and by local coalition of mayors from the towns and villages around the target area for the planned military base, which also actively coordinated its activities with INEZ.
} 
Greenpeace - has concentrated on happenings, performances, and other creative activities, thus illustrating the overall shift in the repertoire of the anti-war movement towards more media-oriented and innovative forms of protests.

After the shift in the opportunity structure of anti-war activism in mid2006, attention immediately turned to the issue of the US base. During 2006, the process of swift anti-war frame amplification ${ }^{27}$ occurred as criticism of the "war on terror' and the foreign policy attempts of the Bush administration to unilaterally disrupt the international balance of power and achieve world hegemony, or the idea of the universal promotion of nonviolence, became only subsidiary arguments in the rhetoric of anti-war activists. The general anti-war argumentation thus narrowed its focus to the issue of the US military radar base in the Czech Republic and concentrated on the particular technical, environmental, security, health, and political consequences of the issue for the local or national audience. In addition, this new anti-war argumentation also avoided the concepts of global political economy and human rights, and slipped to the national level when the installation of the base was likened to the Soviet army's occupation of the country after 1968. In addition, the process of value amplification ${ }^{28}$ occurred as the intention to build a foreign military base was identified as infringing on Czech national sovereignty, and as violating fundamental democratic principles, and citizens' rights and freedoms that were (re-)established after 1989.

\section{Spillover without spillout?}

A casual look at the history of the interaction between the Czech GJM and antiwar activism might appear analogous to the GJM spillout in the US - at least in Hadden's and Tarrow's definition of the concept. All the key GJM actors shifted the main part of their activities and resources to the anti-war movement when they became its organisational backbone upon its inception. First, after the relative flourishing and growth of global justice activism during the late 1990s and its peak in 2000 (owing to a process of transnational diffusion [cf. Kolářová 2009; Tarrow 2005], the number of protest mobilisations on GJM issues and the size of attendance sharply declined after 2002 and global justice SMOs have not been successful in revitalising the protest activities on this issue since then. Second, the model of the social-fora process - while it mushroomed in Western Europe - developed rather weakly in the Czech Republic: most of the movement has never

\footnotetext{
${ }^{27}$ Frame amplification is understood as 'the clarification and invigoration of an interpretive frame that bears on a particular issue, problem or set of events' [Snow et al. 1986: 469].

28 This mechanism is a part of frame amplification process and refers to the identification, idealization, and elevation of one or more values presumed basic to prospective constituents but which have not inspired collective action for any number of reasons' [ibid.].
} 
fully identified with this model of promoting and mobilising on the global justice agenda, and it was never embraced by the other movements and NGOs, the public, or the media. Finally, the global justice SMOs were usually unable to promote and maintain broad organisational coalitions across all the ideological currents that backed these GJM events - in fact, the broadest coherent and operational global justice coalitions were mediated and pushed by transnational activist elites before and during the Prague IMF/WB protests without any lasting impact on local groups [Císař 2008: 151-153; Kolářová 2009: 57]. Furthermore, global justice actors were only rarely successful in involving SMOs from other areas of activism in their causes.

Now we will deal with the assessment of the spillover in particular dimensions of the existence of the GJM trough tracing respective sub-processes or mechanisms, and on considering their actual state.

\section{The framing of public participation}

First, we shall look at the dynamics of the shifting of framing of the GJM's public participation from global justice issues towards anti-war activism [cf. Snow et al. 1986; Benford and Snow 2000]. In the early stage of the Czech GJM's evolution, the original symbolic apparatuses of groups were sufficiently universal and ideologically resonant with the anti-capitalistic globalisation framing and activities that arose in the late 1990s in developed countries. The threat of economic/capitalist globalisation fitted very well into Marxist, socialist, and anarchist philosophies, so it was easily assimilated and internalised by many of the Czech radical left groups, and it supported the unification of their diagnostic and mobilising frames [cf. Benford and Snow 2000: 615]. This enabled the spread of global justice events - in the form of 'street parties' - that often revolved around several issues and despite the mutual animosity of groups involved attracted some public attention. Criticism of neoliberal globalisation gradually became a firm part of their master frames and of their collective identity, widened their operational field, and reinforced new networking patterns thus giving rise to the Czech GJM.

After the massive Prague protests against the IMF/WB in 2000, the number of events framed as 'global justice' and attendance levels at such events rapidly fell [see Císař 2008: 72-73]. Some organising patterns with global justice framing survived (anarchist-oriented events with weakening accent on globalisation issues have since 2000 continued to be held annually in Prague and Brno, and irregular attempts to resurrect social fora process take place in Prague). However, the movement started to place emphasis on other issues and bridge respective frames. Neither environmental nor Third World issues (significant for the European GJM) became dominant in the Czech GJM (they were represented by ideologically hostile groups and NGO networks). On the other hand, the anti-war rhetoric that was implicitly present in previous anti-neoliberal framing schemes 


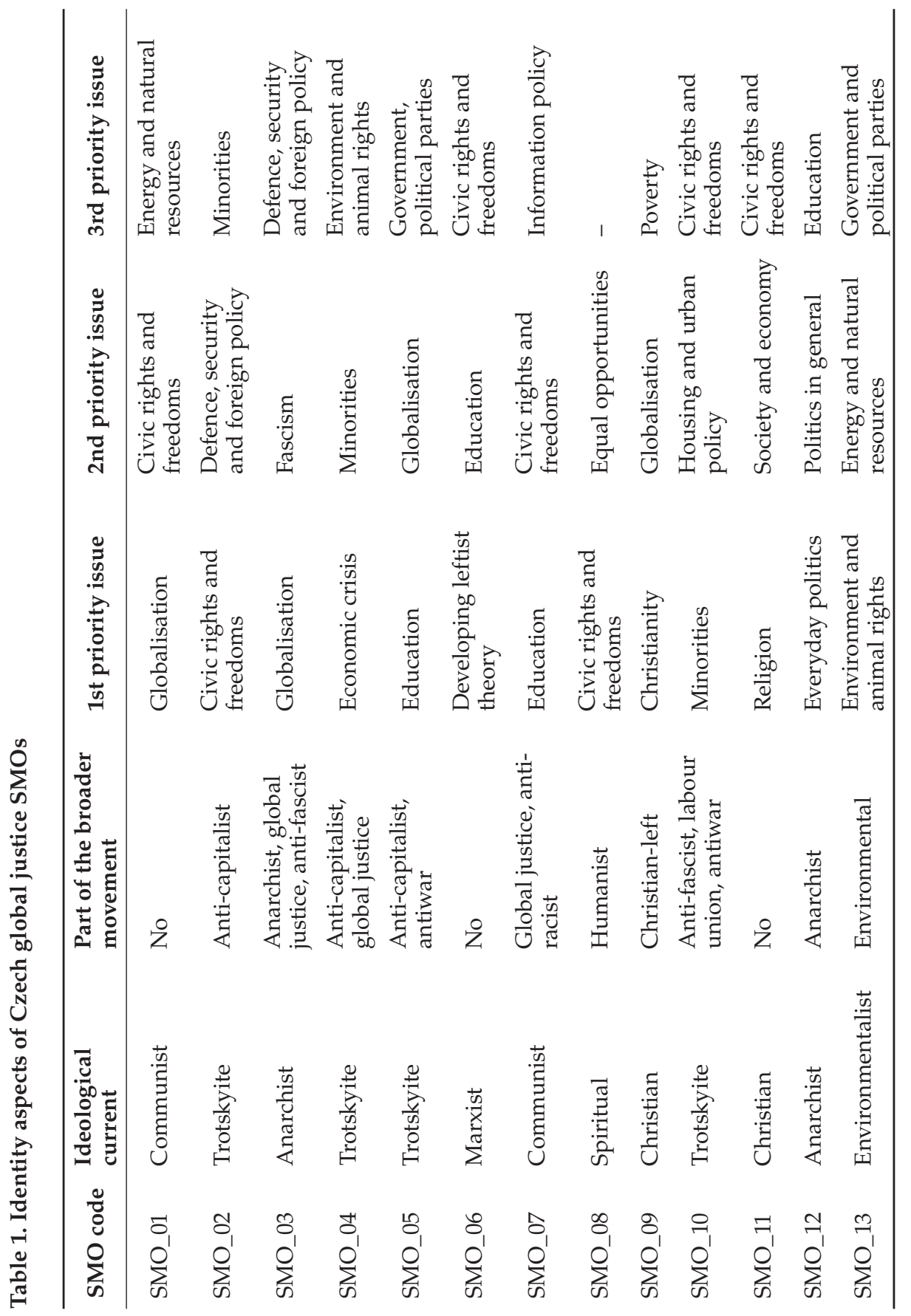




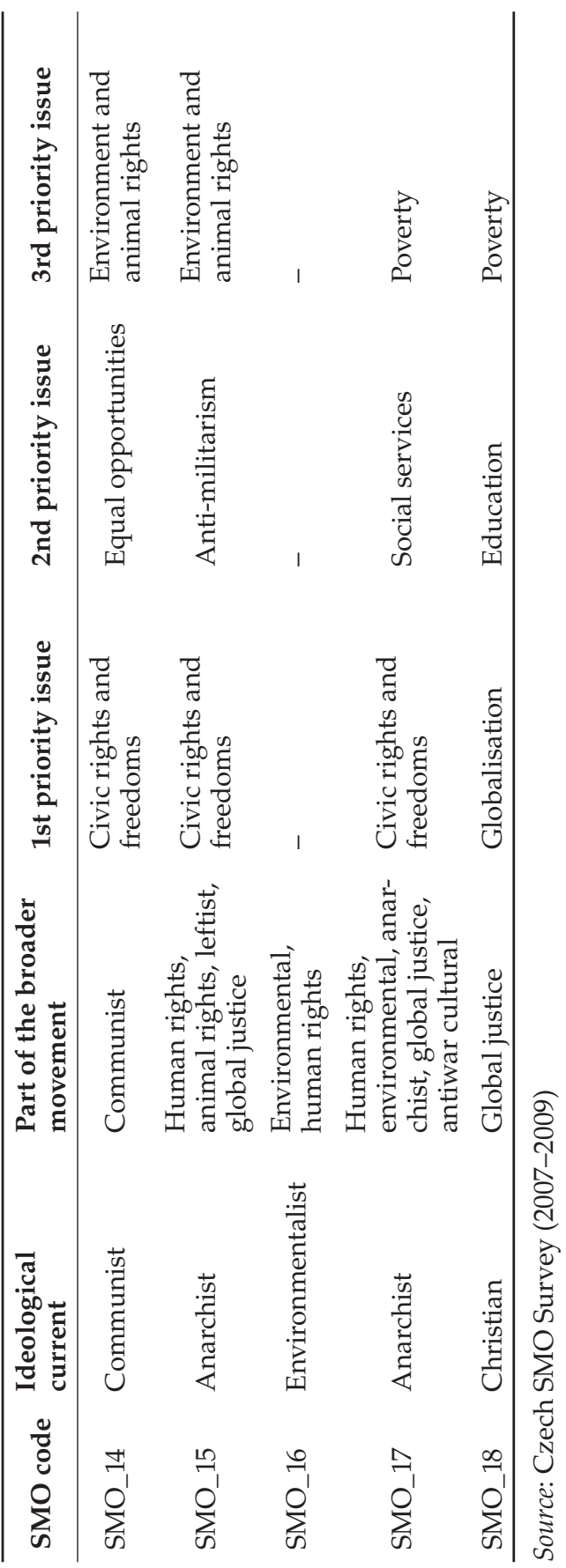


[see also Ayres 2005: 26] was accentuated. Anti-war and anti-capitalist mobilisation frames were closely bridged during the 2002 NATO summit protests, which that the potential to repeat the success of the movement in 2000 because of the transnational character of the event [Kolářová 2009: 50]. After mid-2006, the existing anti-war frame was amplified [cf. Snow et al. 1986: 469] when the wars in Iraq and Afghanistan were transformed into a background argument supporting the domestic resistance to US military presence in the CR; even the framing of 'classic' global justice events as social fora shifted from general anti-capitalist to almost pure and localised anti-war argumentation. Finally, a sub-process of value amplification took place, wherein issues of national sovereignty and direct democracy were highlighted to support the main goal of the anti-war movement.

\section{Networking}

The ideological fragmentation of the Czech GJM was one of its distinctive features from the very beginning and had consequences for coalition building and the coherence of cooperation within the movement. From the time the movement was established, there were three clearly visible cooperating clusters of global justice SMOs: anarchists, Trotskyites and communists - with marginal connections outside these issue areas. Generally, the first of the three aforementioned was the least willing to cooperate with the other two, and there were also tangible tensions between the second and third current. These schisms were overcome for the first time during the preparations for the Prague IMF/WB event in 2000, where anarchists and Trotskyites were able to cooperate (namely because of transnational assistance during the event) and also had informal support from the communists. Characteristically, the non-anarchist left coalition also engaged in its own parallel activities during event. After 2000, the anarchist network was isolated while the other two, and particularly the Trotskyites, were more active in brokering new alliances. Within global justice activism, the Trotskyite and communist organisations more often established coalitions, but they were still unable to create ideologically more divergent and more stable ties, except for a few religious global justice SMOs. Since 2002, the Trotskyites have been more successful and managed to become involved in other issue areas such as religious and single-issue peace activism. As Figure 1 shows, among the organisers of anti-war events between 2003 and 2006, the Trotskyites were also the most successful in brokering effective coalitions with anti-war actors, while both communist and anarchist currents cooperated instead within their own networks. As networking within the global justice arena stagnated or even subsided (as in the case of the cross-national cooperation), networking patterns within anti-war activism expanded considerably after mid-2006. While the anarchists still stayed formally apart, the Trotskyites were able to co-found and (with communists) participate in the broadest anti-war coalition in Czech history. This project consisted of GJM groups, anti-war organisations and other NGOs that had never participated in 
any common coalition before - not even in the large transnational Prague protests in 2000. Despite the fact that both anarchists and communists separately held their own anti-war events, they simultaneously (though sometimes informally) either cooperated with or became a member of INEZ its member. Quite paradoxically then, the global justice actors were able to broker broad and effective cooperation only within the different field of activism.

\section{Collective identity}

There is one key fact that has affected the character and evolution of the collective identity of the Czech GJM: even though several global justice SMOs or their networks only formally established themselves after 2000, all of them had become ideologically developed and solidified in the late 1990s and kept their core attributes (name, organisational independence, ideological affiliation) during and after their involvement in anti-war activism. In contrast to anti-capitalist issues, anti-militarist and anti-war issues have always been minor and secondary in their ideological schemes, and they never became the ultimate rationale for their existence or targets to fight against. Neither of the steps in the strategic frame realignment (2002 and 2006) taken by global justice actors was reflected too intensively in the reshaping of their collective identities, and the movement also retained high cognitive level of collective identity (see the previous section). The only groups that participated on formative global justice events during the late 1990's and in 2000 and that denied having an alter-globalist identity in the survey were environmental groups. At the same time, my sample of 18 Czech global justice SMOs represents all the major ideological currents and actors within the movement (see the previous section and Table 1).

Out of the sample, 16 groups were active in anti-war activism from its very beginning (2003) and constituted its very core in terms of organising public protest events between 2003-2006 and 2006-2009. Nonetheless, only three of them identified themselves as a part of the anti-war movement, while all of them ranked this option as less important than their membership in the global justice, anti-capitalist or other movement. At the same time, even though 12 of these groups labelled themselves (among other things) as 'anti-war', only one of them perceived the issue of militarism as important (ranking it in the second place). Eight groups reported that they are involved in issues of 'defence, security, and foreign policy', but none of them perceived this issue as the most important one for them: only one SMO identified it as the second most important, and one as the third most important issue.

On the other hand, only one group in the sample identified itself exclusively as part of the broader GJM. The alternative collective affiliations of global justice actors were mostly identified as anarchist, anti-fascist, anti-capitalist, religious, or environmental. This suggests that the collective identity of the Czech global 
justice SMOs is based on multiple, mutually coherent symbolical schemes and marked by strong anti-capitalism (whether explicitly radical leftist, or implicitly religious or environmental), even though it was the very global justice identity that enabled them to cooperate across various ideological currents.

To conclude, while the major GJM actors have always been the key organising pillar of Czech anti-war activism since 2003, and brought much of their expertise and resources to this field of contention, they have not respectively transformed their collective identities: the global justice actors involved in anti-war activism have inwardly kept their primary global anti-capitalist conviction even when they outwardly supported both anti-war activism and its overlapping with global justice issues in the domestic context.

\section{Conclusion}

As demonstrated above, the process of social movement spillover may be assessed through its decomposition into several constituent sub-processes such as brokerage, coalition formation, frame bridging, or frame amplification, which have already been identified in various areas of political contention. However, the key mechanism of identity shift that condition the final spillout effect - as defined here - was not identified within the period under study. Accordingly the article suggests that despite the original indicators of the GJM's dynamics (developed by Hadden and Tarrow) that would favour the thesis of the Czech movement spillout, instead we have witnessed its strategic and probably temporary spillover into anti-war initiatives.

More generally, this article attempted to justify the efforts to broaden the concept of spillover from the study of indirect channelling of movement-movement influence to an analysis of the strategic behaviour of a single movement faced with an (unfavourable) environment and/or the seeking out of new opportunities for mobilisation. In my view, Tarrow's and Hadden's concept of spillout aimed at identifying the definite collapse of a movement that is changing its target area raises several questions. Two of them seem most important: whether the fall of the movement may be grasped in an either/or manner, and whether the defining aspect of the social movement is the issue that interconnects and unifies the public protest activities of its members or its more or less hidden collective identity. Relying on the classic notions of social movement abeyance (V. Taylor) or submerged networks (A. Melucci), I am inclined to stress the processual and identity aspect in the study of movement decline. I believe I have demonstrated that the continuance of the shared beliefs and the sense of collective belonging represent the ultimate benchmark of the social movement's dis-/continuity, and subsequently the precondition for its regeneration. 
JIŘí NAVRÁTIL is a researcher at the Institute for Comparative Political Research (Department of Political Science, Faculty of Social Studies, Masaryk University in Brno). His main research interests are collective action and social movements; social network analysis (SNA), and radical political and social theory.

\section{References}

Aguiton, Christophe, Miguel Benasayag, Bernard Cassen, Nadia Demond, Gustave Massiah, Philippe Merlant, Bruno Rebelle, Patrick Viveret, Gilbert Wasserman and Chico Whitaker. 2003. Où va le mouvement altermondialisation? Paris: La Découverte.

Ayres, Jeffrey M. 2005. 'From "Anti-Globalization" to the Global Justice Movement: Framing Collective Action against Neoliberalism.' Pp. 9-27 in Transforming Globalization. Challenges and Opportunities in the Post 9/11 Era, edited by B. Podobnik and T. Reifer. Leiden: Brill.

Bastl, Martin. 2001. Radikální levice v České republice: devadesátá léta dvacátého století. (The Radical Left in the Czech Republic) Brno: IIPS.

Benford, Robert and David Snow. 2000. 'Framing Processes and Social Movements: An Overview and Assessment.' Annual Review of Sociology 26: 611-639.

Bennett, Lance W. 2005. 'Social Movements beyond Borders: Understanding Two Eras of Transnational Activism.' Pp. 203-226 in Transnational Protest E Global Activism, edited by D. Della Porta and S. Tarrow. Lanham: Rowman \& Littlefield Publishers, Inc.

Buttel, Frederick and Kenneth Gould. 2004. 'Global Social Movement(s) at the Crossroads: Some Observations on the Trajectory of the Anti-Corporate Globalization Movement.' Journal of World-Systems Research 10: 37-66.

Císař, Ondřej. 2008. Politický aktivismus v České republice. Socialání hnutí a občasnká společnost v obdobi transformace a europeizace. (Political Activism in the Czech Republic: Social Movements and Civil Society in the Period of Transformation and Europeanisation) Brno: CDK.

Císař, Ondřej. 2010. 'Externally Sponsored Contention: The Channelling of Environmental Movement Organisations in the Czech Republic after the Fall of Communism.' Environmental Politics 19: 736-755.

Císař, Ondřej and Ondřej Slačálek. 2007. 'The Alter-globalization Movement and Democracy in the Czech Republic.' Paper presented at the ECPR Joint Session of Workshops, 7-12 May, Helsinki, Finland.

Crossley, Nick. 2003. 'Even Newer Social Movements? Anti-Corporate Protests, Capitalist Crises and the Remoralization of Society.' Organization 10: 287-305.

Curran, Giorel. 2006 'Whither the Global Justice Movement?' Paper presented at the TASA Conference 2006, University of Western Australia \& Murdoch University, 4-7 December.

Della Porta, Donatella (ed.). 2007. The Global Justice Movement. Cross-national and Transnational Perspectives. Boulder: Paradigm Publishers.

Della Porta, Donatella and Mario Diani. 2006. Social Movements. An Introduction. Oxford: Wiley-Blackwell.

Della Porta, Donatella and Lorenzo Mosca. 2007. 'In movimento: "Contamination" in Action and the Italian Global Justice Movement.' Global Networks 7: 1-27.

Della Porta, Donatella and Sidney Tarrow (eds.). 2005. Transnational Protest and Global Activism. Lanham: Rowman \& Littlefield Publishers, Inc. 
Della Porta, Donatella, Abby Peterson and Herbert H. Reiter (eds.). 2006. The Policing of Transnational Protest. Aldershot: Ashgate.

Fernandez, Luis A. 2008. Policing Dissent. Social Control and the Anti-Globalization Movement. New Brunswick: Rutgers University Press.

Fisher, Dana R. 2007. 'Taking Over Beneath the Anti-Bush Umbrella: Cycles of Protest and Movement-to-Movement Transmissions in an Era of Repressive Politics.' Politics and Globalization, Research in Political Sociology 15: 27-55.

Giugni, Marco, Marko Bandler and Nina Eggert. 2006. ‘The Global Justice Movement. How Far Does the Classic Social Movement Agenda Go in Explaining Transnational Contention?' Civil Society and Social Movements Programme Paper No. 24. Geneva: United Nations Research Institute for Social Development.

Hadden, Jennifer and Sidney Tarrow. 2007. 'Spillover or Spillout? The Global Justice Movement in the United States after 9/11.' Mobilization 12: 359-376.

Hanley, Seán. 2001. 'Towards Breakthrough or Breakdown? The Consolidation of KSCM as a Neo-communist Successor Party in the Czech Republic.' Journal of Communist Studies $\mathcal{E}$ Transition Politics 17: 96-116.

Held, David and Anthony McGrew. 2007. Globalization/Anti-Globalization. Cambridge: Polity Press.

Hosseini, S.A. Hamed. 2010. Alternative Globalizations. An Integrative Approach to Studying Dissident Knowledge in the Global Justice Movement. Abingdon: Routledge.

Hunt, Scott A. and Robert D. Benford. 2004. 'Collective Identity, Solidarity, and Commitment.' Pp. 433-457 in The Blackwell Companion to Social Movements, edited by D. A. Snow, S. A. Soule and H. Kriesi. Malden: Wiley-Blackwell.

Juris, Jeffrey S. 2008. Networking Futures. The Movements against Corporate Globalization. London: Duke University Press.

Keck, Margaret E. and Kathryn Sikkink. 1998. Activists Beyond Borders. Advocacy Networks in International Politics. London: Cornell University Press.

Kolářová, Marta. 2008. 'Antiglobalismus.' (Anti-globalism) Socioweb 4/08: 3-5.

Retrieved 12 October 2009

(http://www.socioweb.cz/index.php?disp=teorie\&shw=324\&lst=108).

Kolářová, Marta. 2009. Protest proti globalizaci. Gender a feministická kritika. (Protest against Globalisation: Gender and Feminist Critique) Prague: SLON.

Kolb, Felix. 2005. 'The Impact of Transnational Protest on Social Movement

Organizations: Mass Media and the Making of Attac Germany.' Pp. 95-120 in Transnational Protest and Global Activism, edited by D. Della Porta and S. Tarrow. Lanham: Rowman \& Littlefield Publishers, Inc.

Kunštát, Daniel. 2004. 'Veřejná podpora KSČM po roce 1989: historická východiska, politické a sociální souvislosti, perspektivy.' (Public Support for KSČM after 1989: Historical Departures, Political and Social Connections, Perspectives) Naše společnost 2004: 1. Retrieved 15 March 2009

(http://www.cvvm.cas.cz/upl/nase_spolecnost/100033s_Kunstat-kscm.pdf).

March, Luke and Cas Mudde. 2005. 'What's Left of the Radical Left? The European

Radical Left After 1989: Decline and Mutation.' Comparative European Politics 3: 23-49.

McAdam, Doug, Sidney Tarrow and Charles Tilly. 2001. Dynamics of Contention. Cambridge: Cambridge University Press.

Meyer, David S. and Nancy Whittier. 1994. 'Social Movement Spillover.' Social Problems 41: 277-297.

Munck, Ronaldo. 2007. Globalization and Contestation. Abingdon: Routledge.

Paczyńska, Agnieszka. 2008. 'Turtles, Puppets and Pink Ladies: The Global Justice Movement in a Post-9/11 World.' Working Paper in Global Studies No. 1. Retrieved 6 January 2009 (http://cgs.gmu.edu/publications/gswp/gs_wp_1.pdf). 
Pianta, Mario. 2001. 'Parallel Summits of Global Civil Society.' Pp. 169-194 in Global Civil Society 2001, edited by H. Anheier, M. Glasius and M. Kaldor. Oxford: Oxford University Press.

Pianta, Mario. 2005. 'UN World Summits and Civil Society. The State of the Art.' Civil Society and Social Movements Programme Paper No. 18. Geneva: United Nations Research Institute for Social Development. Retrieved 6 January 2009 (http://www.unrisd. org/80256B3C005BCCF9 / (httpAuxPages) /5709F9C06F40FDBAC12570A1002DC4D2/ \$file/pianta.pdf).

Pianta, Mario and Raffaele Marchetti. 2007. 'The Global Justice Movements. The Transnational Dimension.' Pp. 29-51 in The Global Justice Movement. Cross-national and Transnational Perspectives, edited by D. Della Porta. Boulder: Paradigm Publishers.

Podobnik, Bruce. 2005. 'Resistance to Globalization: Cycles and Trends in the Globalization Protest Movement.' Pp. 51-68 in Transforming Globalization. Challenges and Opportunities in the Post 9/11 Era, edited by B. Podobnik and T. Reifer. Leiden: Brill.

Rothman, Franklin Daniel and Pamela E. Oliver. 2002. 'From Local to Global: The Anti-dam Movement in Southern Brazil, 1979-1992.' Pp. 115-132 in Globalization $\mathcal{E}$ Resistance: Transnational Dimensions of Social Movements, edited by J. Smith and H. Johnston. Lanham: Rowman \& Littlefield Publishers, Inc.

Routledge, Paul. 1996. 'Resisting and Reshaping the Modern: Social Movements and the Development Process.' Pp. 263-279 in Geographies of Global Change: Remapping the World in the Late Twentieth Century, edited by R. J. Johnston, P. J. Tailor and M. J. Watts. Oxford: Blackwell Publishers.

Ruggiero, Vincenzo. 2002. “'Attac”: A Global Social Movement?' Social Justice 29: 48-60.

Rủžička, Vlastimil. 2007. Squaty a jejich revoluční tendence. (Squats and Their Revolutionary Tendencies) Prague: Triton.

Seohane, José and Emilio Taddei. 2002. 'From Seattle to Porto Alegre: The AntiNeoliberal Globalization Movement.' Current Sociology 50: 99-122.

Slačálek, Ondřej. 2000. 'Stručná historie českého anarchistického hnutí.' (A Brief History of the Czech Anarchist Movement) A-kontra 8/2000. Retrieved 6 January 2009 (http://wiki.csaf.cz/encyklopedie:strucna_historie_ceskeho_anarchistickeho_hnuti).

Smith, Jackie. 2008. Social Movements for Global Democracy. Baltimore: The Johns Hopkins University Press.

Snow, David, Burke E. Rochford, Steven K. Worden and Robert D. Benford. 1986. 'Frame Alignment Processes, Micromobilization, and Movement Participation.' American Sociological Review 51: 464-481.

Staggenborg, Suzanne. 2008. Social Movements. Oxford: Oxford University Press.

Starr, Amory. 2000. Naming the Enemy. Anti-Corporate Movements Confront Globalization. Annandale: Pluto Press.

Szabó, Máté. 1996. 'Repertoires of Contention in Post-Communist Protest Cultures: An East Central European Comparative Survey.' Social Research 63: 1155-1182.

Tarrow, Sidney. 2005. The New Transnational Activism. New York: Cambridge University Press.

Tarrow, Sidney and Donatella Della Porta. 2005. 'Conclusion: “Globalization," Complex Internationalism, and Transnational Contention.' Pp. 227-246 in Transnational Protest and Global Activist, edited by Donatella Della Porta and Sidney Tarrow. Lanham: Rowman \& Littlefield Publishers, Inc.

Tilly, Charles and Sidney Tarrow. 2007. Contentious Politics. Boulder: Paradigm Publishers.

Walton, John and Charles Ragin. 1990. 'Global and National Sources of Political Protest: Third World Responses to the Debt Crisis.' American Sociological Review 55: 876-890. 
Welsh, Ian. 2004. 'Network Movement in the Czech Republic: Peturbating Prague.' Journal of Contemporary European Studies 12: 321-337.

Whittier, Nancy. 2005. 'The Consequences of Social Movements for Each Other.' Pp. 531-551 in The Blackwell Companion to Social Movements, edited by D. A. Snow, S. A. Soule and H. Kriesi. Malden: Wiley-Blackwell.

Wilkin, Peter. 2003. 'Against Global Governance? Tracing the Lineage of the AntiGlobalisation Movement.' Pp. 78-95 in Global Governance, Conflict and Resistance, edited by F. Cochrane, R. Duffy and J. Selby. Houndmills: Palgrave Macmillan.

\section{Data sources}

Czech SMO Survey (2007-2009). Conducted by the Institute for Comparative Political Research at the Faculty of Social Studies, Masaryk University in Brno. See http://ispo.fss.muni.cz/zajmy (Retrieved 17 December 2010). 